\author{
International Journal of Linguistics, Literature and Translation (IJLLT) \\ ISSN: 2617-0299 (Online); ISSN: 2708-0099 (Print) \\ DOI: $10.32996 / \mathrm{ijllt}$ \\ Journal Homepage: www.al-kindipublisher.com/index.php/ijllt
}

IJLLT

\title{
Traces and Roots: Exploring Lexical Rapport of the Bisayan and Tausug Languages
}

\author{
Sharifa Khalid Masorong \\ English Department, College of Social Sciences and Humanities, Mindanao State University, Marawi City, Philippines \\ $\triangle$ Corresponding Author: Sharifa Khalid Masorong, E-mail: sharifa.masorong@msumain.edu.ph
}

\author{
ARTICLE INFORMATION \\ Received: December 22, 2020 \\ Accepted: February 17, 2021 \\ Volume: 4 \\ Issue: 2 \\ DOI: $10.32996 / i j l l t .2021 .4 .2 .15$
}

\section{KEYWORDS}

Language, culture, Malayo

Polynesian Languages,

Austronesian Languages, Cultural

Identity, Translation, Asian

Languages

\section{ABSTRACT}

Languages in a country are considered to share common characteristics and possibly similar features. This can be attributed to many factors, but one holds true, language is essential in keeping a community. Its vitality molds a society's identity. The more active the language is, the more its culture gets the exposure it needs. This notion goes two ways for culture cannot also stand without the usage of a language. In this study, Bisayan and Tausug lexicons were compared using a Samarin list to identify factors of similarities as well as their relationship in terms of their semantic and ontological categories. The list was subjected to a qualitative-descriptive analysis. The result of the study revealed that both Tausug and Bisayan (Cebuano) cultures have come from the same linguistic family. Both belong to the Philippine VISAYAN LANGUAGES. Of all the Visayan cultures, the TAUSUG is a Muslim dominated culture which makes it the reason why people associate Tausug language as part of the Mindanao language. The study showed that of the 200 lexicons used based on a Samarin list, 72 of those are true cognates and 28 are cognates with few differences and changes in the spelling. The findings also indicate that these similarities can be attributed to different factors like tracing language relationship by means of genetics, the environmental changes, the language sounds and language arbitrariness.

\section{Introduction}

Languages in each country are considered to share common characteristics and possibly similar features. This can be attributed to many factors, but one holds true, language is essential in keeping a community and a country alive. The vitality of a language can keeps the identity of a certain community. The more lovely and active the language is, the more exposure and chances will become available to the culture it carries. Languages would be inexistent without culture. This notion goes two ways for culture cannot also stand with the usage of a language. Language keeps a community intact. According to Benjamin Whorf, a language creates and establishes a person's perceptions in life and of reality for languages shapes his thoughts and ideas. This is indeed a fact that o person's reality is defined by the truth he believes in and in return make up who he is and how he sees the world. How people use the language can contribute to how he sees the world and how he attacks and takes problems and issues. Language is not just all about symbols or words, but it represents signs that cannot be just interpreted with mere words and utterances but with actions and gestures.

Language also paves way for making strong relationships and establishing bonds. It is a tool that the society needs in order to interact and understand each other better. It is a given truth that our language can be used to express the social status quo as well as the social and cultural phenomenon. Edward Sapir sees that a language is not just all about expressing one's deep thoughts and analysis, but it also represents a 'fundamental expression of a social identity (Kilgour, 1999). Our behavior, beliefs, unique features, and characteristics are all part of our social identity. Henry Tajfel (1979) that a person finds solace, pride and belongingness from the group he belongs in. This would mean that our society or social group gives us a sense of identity. This group could come as a family, a team, a social class or even a culture. Our identity then is dependent on the group or culture we grew up with. Thus, a language is also very important in our self- image and cultural identity. The society that every individual life in activates social relationship by exposure and interacting with people in the surrounding societies as well. The Philippines has

K C AL-KINDI CENTER $\mathbf{R}$ FOR RESEARCH AND $\mathbf{D}$ DEVELOPMENT Your gateway to world-class research

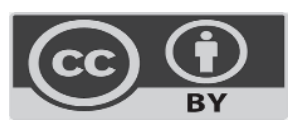

Published by Al-Kindi Center for Research and Development. Copyright (c) the author(s). This open access article is distributed under a Creative Commons Attribution (CC-BY) 4.0 license 
various distinct societies depending on the culture that they adapted to. The culture at some point dictates the language that the community uses that is unique to them.

Two of these cultures are that of the Tausugs and the Bisayans (specific in Mindanao cultures). The Tausugs have unique features when it comes to their language. The Tausug word is derived from the word 'TAU' which means man and 'SUG' which means current, thus, the concept that Tausug is 'a man of current.' They are called so because of their geographical placement in Sulu Archipelago which is near the sea. Because of their location, their livelihood depends on the sea and most of them are divers for pearls, fishermen and traders. Their language is very active and vital for they use the Bahasa Sug on a daily basis. The Tausugs are known to be brave and very conscious of kinship. They are also very aware of their cultural identity. The Tausugs are the first tribe to be Islamized from the group of major Muslim tribes in Mindanao and they embraced Islam and based their orthography in Arabic.

Bisaya, on the other hand, refers to a group of languages of the Philippines. The cultures that use Bisaya as their first language are plenty and how they understand the language also differs. Most of the Bisayans are located in Luzon and most areas in Mindanao. Of these groups, Cebuano speakers take the largest group.

Both the Tausugs and the Bisayas are said to be under the same family--- the Austronesian languages. Both use their vernacular for them to be identified and belong to the culture that they represent. This identification keeps a society one for it functions as their means of getting along and interacting.

Language, on the outset, consists of different symbols and sounds that represent meaning to a certain culture. Learning a language is a natural phenomenon and, in most cases, learning falls into understanding words and their meaning. This, in language component, means the lexicon. Lexicon is part of a language that is indispensable because of its essential part in a sentence. Lexicon refers to the vocabulary used in a language. It could mean tracing the ancient language and its origin or the special vocabulary that is of present to a culture. In the linguistics word, it refers a 'stock of words and words element that carry meaning.' Accordingly, it came from the word lexicon which means "word" (https://www.vocabulary.com/dictionary/lexicon). In other cases, the wider study of recording of word and its varied meanings is termed as lexicography. As mentioned, the lexicons play important roles in understanding a culture and the language that they use. Lexicons contribute to the over- all meaning and significance of an utterance. This template is formatted according to advice of some experts. All settings about fonts, point sizes and line spacing have been defined in the styles menu. (Figure 1) Use this document as a template if you are using Microsoft Word 2003 or higher. The Manuscript length should contain 5 pages at least. It should be in a two-column format. In general, a full manuscript consists of "Introduction", "Objectives", "Methods", "Results", "Discussion" and "Conclusions". English is treated as the only written language throughout the text.

\section{Literature Review}

In this part of the paper, the literature and other related studies that are considered important in better understanding the topic being undertaken are discussed in order to give theoretical support. This is also the section the related studies that are related to the importance of lexicons and lexicography, origin of language as well as theories used in this study.

\section{Language and Culture}

Language is powerful, lie and instrument of a culture, the instrument of domination and liberation. $\quad$ Angela Carter

Language is indeed a vital tool in a community and without it, a culture may seem non-existent. There had been theories discussing how language has originated and how language learning takes place. For Naom Chomsky (1960), he has this notion that children or people learn because of the innate capacity of people to know things-what is and what is not. He has this notion that all persons have the same structural processes when it comes to learning a language; that language is made of different rules and principles that people are unaware of. These rules, according to him, enable people to understand each other at some point.

Behaviorists' version is that language learning is possible because of the environmental factors. Through the exposure they have, the children can develop their skills and competence. It is the idea that what children learn because they have this 'internal monitor' that allows them to process what they hear. They start to do certain habits out from what they perceived. There are, of course, various theories that are created to contradict tor to support those claims but it often boils down to one-language is an important tool in thinking and in identifying one's identity. 
Language is something closely related to importance of culture's existence. Language and culture are somewhat partners that are inseparable. There are some researches which dispute such relationship. They stand by the notion that language is actually shaped by one's cognition and not culture. Again, all these theories would become an evidence that there is really a bond between the two. When you understand a language of a community, you can also understand their culture and vice versa.

\section{Traces of Austronesian Languages}

Philippines languages are considered as member of the Austronesian languages family and just like language and culture, it has sprung many theories. Different versions have come up but often lead to a universal truth. The purpose of these theories is to establish the relationship of these languages in terms of origin, location or even their connection. One known theory is that of Robert Blust. He has this theory of dispersal. He demonstrated connection between two groups and further grouped them.

In a nutshell, he has grouped those in Western side and other in the central eastern side. This is like that of a migration theory but his is termed 'dispersing' of languages. Sapir (1916) and Dyen (1956) focused on the migration theory to show similarities between two languages. Just like that of Blust, they had also mentioned that the area with many numbers of migrants is said to be the center or main source of the Austronesian languages. Earlier theories focused on the concept that Philippine languages are grouped according to landscape or location. This is often the basis of many researchers and considers geography to have a great impact in understanding a language or a culture. Pawley (1975) introduced the 'lexicons' based on the common terms in all the languages and used those as a means or basis on his assumption that the source of the Austronesian languages is from that of those areas rich in agriculture.

\section{Lexicons and Lexicography}

Lexicon is an integral part of a language. Lexicons make up the languages used in a community. Many linguists study lexicons called lexicography in order to better understand the other component of a language. The main concern of lexicography is the studying of 'lexicon' that is present in a language. Lexicons are used and studied for it is closely related to the language's phonetics or grammar.

\section{Research Design and Methodology}

This is a study that is qualitative- descriptive in nature. The listing of similar lexicons of the Tausug and Bisaya languages were categorized by means of two categories: the semantic field and ontological features. These categories and similarities were then identified and interpreted to know the relationship of the Tausug and Bisaya languages which are opposites in its dominant users: Tausug as Muslim dominant culture while Bisaya as mainly non-Muslims.

\subsection{Locale of the Study}

There are various cultures present in Mindanao and their languages are often linked at one point in their utterances. These languages contribute to the rich cultures seen in the Island. The researcher did not have to go that for both languages are accessible in the locale of the study.

\subsection{Procedure of Data Analysis}

Both the Tausug and the Bisaya are unique in their culture and their languages but there are some words that are identical in meaning and in usage. A language has different components, and these components make up the uniqueness of a certain culture. In this study, the researcher focused on words and its meanings also known the lexicons. The lexicons used is based on a modified Samarin list which is combination of Swadesh List (1955) and Gudschinsky (1956). The research paper's data were gathered by means of field research. For the Tausug, the researcher had done phone interview as had been discussed by Labov (1972). The researcher used three informants of different ages. Two were asked to translate the words through phone since they are residing in Basilan and the last one was for validation and done on personal interview. For the gathering of Bisayan lexicons, the researcher had two informants from lligan City and they were personally interviewed. After the data were gathered, they were categorized using the Concepticon's categorization by semantic field and ontological categorization. Through the categorization, the words then were studied by checking the similar lexicons for both the Tausug and Bisaya languages.

\section{Results and Discussion}

For a systematic presentation, the data that were gathered are presented, studied and analyzed based on the arrangement of the problems written in the statement of the problem.

1. What are the lexicons that are similar to both the Tausug and Bisayan languages? 
A. Out of the 196 words listed in the Samarin list, there are 72 lexicons that are of true cognates. The meanings and how they are pronounced are the same.

\begin{tabular}{|c|c|c|c|c|c|}
\hline ENGLISH & TAUSUG & BISAYA & ENGLISH & TAUSUG & BISAYA \\
\hline Hand & Kamut/lima & Kamut & Open & Ukab & Abli/ukab \\
\hline Swim & Langoy & Langoy & Pound/Beat & dukduk & dukduk \\
\hline Dust & abug & Abug & Dog & Iru & Iru \\
\hline Skin & Panit & Panit & Fat & Tambuk & Tambuk \\
\hline Belly & Tadul/tiyan & Tiyan & Tail & Ikug & Ikug \\
\hline Bone & Bukug & Bukug & Snake & Ha's & Ha's \\
\hline Liver & Atay & Atay & Spider & Lawa & Lawa \\
\hline Shoulder & Abaga; & Abaga & Branch & Sanga & Sanga \\
\hline Tongue & Dila & Dila & Leaf & Dahun & Dagun \\
\hline Laugh & Katawa & Kataw & Root & Gamut & Gamut \\
\hline Vomit & Suka & Suka & Fruit & Bunga & Bunga \\
\hline Eat & Kaun & Kaun & Stone & Batu & batu \\
\hline Chew & Mama & Mama & Sand & Balas & balas \\
\hline Cook & Luto & Luto & Water & Tubig & Tubig \\
\hline Suck & Supsup & Supsup & Salt & Asin & $A \sin$ \\
\hline Hear & dungog & Dungog & Sky & Langit & Langit \\
\hline Eye & Mata & Mata & Moon & Bulan & Bulan \\
\hline See & Kita & Kita & Cloud & gabun & Gabun \\
\hline Sleep & Tuug & Tug & Lightning & Kilat & Kilat \\
\hline Sit & Lingkud & Lingkud & Wet & Basa & basa \\
\hline Stand & Tingkud & Tingkud & Heavy & Bug-at & Bug-at \\
\hline Husband & Bana & Bana & Burn & Sunog & Sunog \\
\hline Wife & Asawa & Asawa & Smoke & Asu & Asu \\
\hline Roof & Atup & Atup & Black & Itum & Itum \\
\hline Sew & Tahi & Tahi & White & Puti & Puti \\
\hline Kill & buno & Buno & Red & Pula & pula \\
\hline Die & Matay & matay & Old & Maas/daan & Daan \\
\hline Alive & Buhi & Buhi & Day & Adlaw & adlaw \\
\hline Wood & Kahuy & kahuy & Above & babaw & Babaw \\
\hline Sharp & Hait & Hait & All & Katan & tanan \\
\hline Plant & Tanum & Tanum & Four & Upat & upat \\
\hline Swell & Hubag & hubag & We & Kita & kita \\
\hline Hold & Kaput & Gunit/kaput & You & Ikaw & Ikaw \\
\hline I & AKo & Ako & They & Sila & Sila \\
\hline Thou & Ako & Ako & $\mathrm{HE} / \mathrm{SHe}$ & siya & siya \\
\hline
\end{tabular}

B. Of the 196 words, 27 lexicons are cognates but there are only few changes in spelling or in the word's stress with dropping or adding of letter.

\begin{tabular}{|l|l|l|l|l|l|}
\hline ENGLISH & TAUSUG & BISAYA & ENGLISH & TAUSUG & BISAYA \\
\hline Left & Ha lawah & wala & Star & Bituun & Bitoon \\
\hline Right & Hatuuh & tuo & Rain & Ulan & Uwan \\
\hline Road & Kasada & Karsada & Thunder & Dawgdug & Dalugdug \\
\hline Come & Kari & Ari/anhi & New & Bahgu & Bag'u \\
\hline Blood & Dugu & Dugo & Below & Laum & Ilalum \\
\hline Head & Uu & Ulo & This & Ini & Kini \\
\hline Neck & Liug & Liog & Far & Malayu & Layu \\
\hline Hair & Buuk & Buhuk & Two & Duwa & duha \\
\hline
\end{tabular}




\begin{tabular}{|l|l|l|l|l|l|}
\hline Nose & Ngilong/ilung & Ilong & Die & Matay & mamatay \\
\hline Sleep & Tuug & Tulog & Split & Sipak & tipak \\
\hline Person & Tau & Tawu & To fly & Lumupad & lupad \\
\hline Woman & Babai & Babayi & Fish & Ista & Isda \\
\hline House & Bay & Balay/bay & Grass & Bayli & balili \\
\hline Needle & Jawm & Dagum & & & \\
\hline
\end{tabular}

2. In what categorization do these similarities fall in terms of semantic field and ontological categories?

The semantic field would give the groupings of lexical items that fall under the same category based on their meaning. In linguistics, it is also known as lexical field analysis.

Ontological category, on the other hand, refers to the groupings according to the lexicon's relation in terms of its natural being, existence or becoming as perceived by the users of the language.

A. Out of the 196 lexicons from the Samarin list, the most common ONTOLOGICAL category they fall on is the PERSON/THING, followed by ACTION/PROCESS then PROPERTY. Two words from the 72 lexicons fall on OTHER.

In the SEMANTIC FIELD, most similar lexicons are of MOTION, PHYSICAL WORLD, SENSE PERCEPTION, KINSHIP and AGRICULTURE/VEGETATION.

\begin{tabular}{|c|c|c|c|}
\hline ENGLISH & TAUSUG/BISAYA & Semantic FIELD & Ontological category \\
\hline Hand & Kamut/lima & The body & Person/thing \\
\hline Eye & Mata & The body & Person/thing \\
\hline Skin & Panit & The body & Person/thing \\
\hline Belly & Tadul/tiyan & The body & Person/thing \\
\hline Bone & Bukug & The body & Person/thing \\
\hline Liver & Atay & The body & Person/thing \\
\hline Shoulder & Abaga; & The body & Person/thing \\
\hline Tongue & Dila & The body & Person/thing \\
\hline Tail & Ikug & The body & Person/thing \\
\hline Wood & Kahuy & Physical world & Person/thing \\
\hline Dust & abug & Physical world & Person/thing \\
\hline Sand & Balas & Physical world & Person/thing \\
\hline Water & Tubig & Physical world & Person/thing \\
\hline Stone & Batu & Physical world & Person/thing \\
\hline Sky & Langit & Physical world & Person/thing \\
\hline Moon & Bulan & Physical world & Person/thing \\
\hline Cloud & gabun & Physical world & Person/thing \\
\hline Lightning & Kilat & Physical world & Person/thing \\
\hline We & Kita & kinship & Person/thing \\
\hline You & Ikaw & kinship & Person/thing \\
\hline They & Sila & kinship & Person/thing \\
\hline He/She & Siya & kinship & Person/thing \\
\hline Thou & Ako & kinship & Person/thing \\
\hline Husband & Bana & kinship & Person/thing \\
\hline Wife & Asawa & kinship & Person/thing \\
\hline Branch & Sanga & Agri./vegetation & Person/thing \\
\hline Leaf & Dahun & Agri./vegetation & Person/thing \\
\hline
\end{tabular}




\begin{tabular}{|c|c|c|c|}
\hline Root & Gamut & Agri./vegetation & Person/thing \\
\hline Fruit & Bunga & Agri./vegetation & Person/thing \\
\hline Snake & Ha's & animal & Person/thing \\
\hline Spider & Lawa & animal & Person/thing \\
\hline Dog & Iru & animal & Person/thing \\
\hline Fat & Tambuk & Spatial relations & Person/thing \\
\hline Salt & Asin & Food and drink & Person/thing \\
\hline Roof & Atup & The house & Person/thing \\
\hline Cook & Luto & motion & Action/process \\
\hline Suck & Supsup & motion & Action/process \\
\hline Hear & dungog & motion & Action/process \\
\hline See & Kita & motion & Action/process \\
\hline Sleep & Tuug & motion & Action/process \\
\hline Sit & Lingkud & motion & Action/process \\
\hline Stand & Tingkud & motion & Action/process \\
\hline Sew & Tahi & motion & Action/process \\
\hline Kill & buno & motion & Action/process \\
\hline Die & Matay & motion & Action/process \\
\hline Plant & Tanum & motion & Action/process \\
\hline Swell & Hubag & motion & Action/process \\
\hline Hold & Kaput & motion & Action/process \\
\hline Open & Ukab & motion & Action/process \\
\hline Pound/Beat & dukduk & motion & Action/process \\
\hline Burn & Sunog & motion & Action/process \\
\hline Smoke & Asu & motion & Action/process \\
\hline Swim & Langoy & motion & Action/process \\
\hline Sharp & Hait & Sense perception & Property \\
\hline Wet & Basa & Sense perception & Property \\
\hline Heavy & Bug-at & Sense perception & Property \\
\hline Black & Itum & Sense perception & Property \\
\hline White & Puti & Sense perception & Property \\
\hline Red & Pula & Sense perception & Property \\
\hline Alive & Buhi & The body & Property \\
\hline Day & Adlaw & Time & Property \\
\hline Above & babaw & Spatial relations & Property \\
\hline All & Katan & Cognition & Other \\
\hline Four & Upat & Quantity & Other \\
\hline
\end{tabular}

B. In the other set of cognates, it has almost the same with the TRUE cognates where category falls on PERSON/THING, ACTION/PROCESS and PROPERTY. In the SEMANTIC FIELD, what is dominant is that of BODY, Physical world and motion.

\begin{tabular}{|c|c|c|c|c|}
\hline ENGLISH & TAUSUG & BISAYA & Semantic FIELD & Ontological category \\
\hline Left & Ha lawah & wala & The body & Person/thing \\
\hline Right & Hatuuh & tuo & The body & Person/thing \\
\hline Blood & Dugu & Dugo & The body & Person/thing \\
\hline Head & Uu & Ulo & The body & Person/thing \\
\hline Neck & Liug & Liog & The body & Person/thing \\
\hline
\end{tabular}




\begin{tabular}{|c|c|c|c|c|}
\hline Hair & Buuk & Buhuk & The body & Person/thing \\
\hline Nose & Ngilong/ ilung & llong & The body & Person/thing \\
\hline Star & Bituun & Bitoon & Physical world & Person/thing \\
\hline Rain & Ulan & Uwan & Physical world & Person/thing \\
\hline Thunder & Dawgdug & Dalugdug & Physical world & Person/thing \\
\hline Road & Kasada & Karsada & physical world & Person/thing \\
\hline Person & Tau & Tawu & Kinship & Person/thing \\
\hline Woman & Babai & Babayi & Kinship & Person/thing \\
\hline Fish & Ista & Isda & Animal & Person/thing \\
\hline Grass & Bayli & balili & Agri./vegetation & Person/thing \\
\hline House & Bay & Balay/bay & The house & Property \\
\hline Needle & Jawm & Dagum & Clothing & Property \\
\hline Below & Laum & Ilalum & Spatial relations & Property \\
\hline This & Ini & Kini & Spatial relations & Property \\
\hline Far & Malayu & Layu & Spatial relations & Other \\
\hline New & Bahgu & Bag'u & Time & Action/process \\
\hline Two & Duwa & duha & Quantity & Action/process \\
\hline Die & Matay & mamatay & Motion & Action/process \\
\hline Come & Kari & Ari/ anhi & Motion & Action/process \\
\hline Split & Sipak & Tipak & Motion & Motion \\
\hline To fly & Lumupad & Lupad & Motion & \\
\hline Sleep & Tuug & Tulog & & \\
\hline
\end{tabular}

3. What are the implications of these cognates in terms of the lexical rapport between the Bisayans and Tausugs?

Based on the findings in problem 2, it shows that most words that are similar to both Tausug and Bisaya are things, people and action. It shows that most words are those that are considered 'functional'. When it is 'functional', it is basically used on a daily basis. Action or processes happen every day and the things and people attached to it are also used every day. It would show that both Tausugs and Bisayas are one and the same in most of their expressions.

The Philippines said to come from ONE family and that is the MALAYO POLYNESIAN languages which later on became the AUSTRONESIAN languages. The initial theory is that people had migrated from Taiwan to the different nearby Islands. The prominent theory of William Solhiem (1975) -- "NUSANTO" model--- attracted many criticisms because of his notion that Austronesian languages were scattered because of the need of non-Austronesian speakers to establish relationships with warriors and traders. This idea of a MIGRATION theory, however, started different theories in the spread of the Austronesian languages. Languages, according to the Genetic Linguistics Relationship, are genetically related. They are branched from on family. Since the cultures in the Philippines have the same linguistic roots, there are, as it should be, similarities. These similarities may only be varied in pronunciations or spelling. One factor could be the geography influence to the language. The nearer the cultures are, the more possibilities of more similarities. Tracing the Malayo Polynesian subgrouping, here is how the languages are spread. 


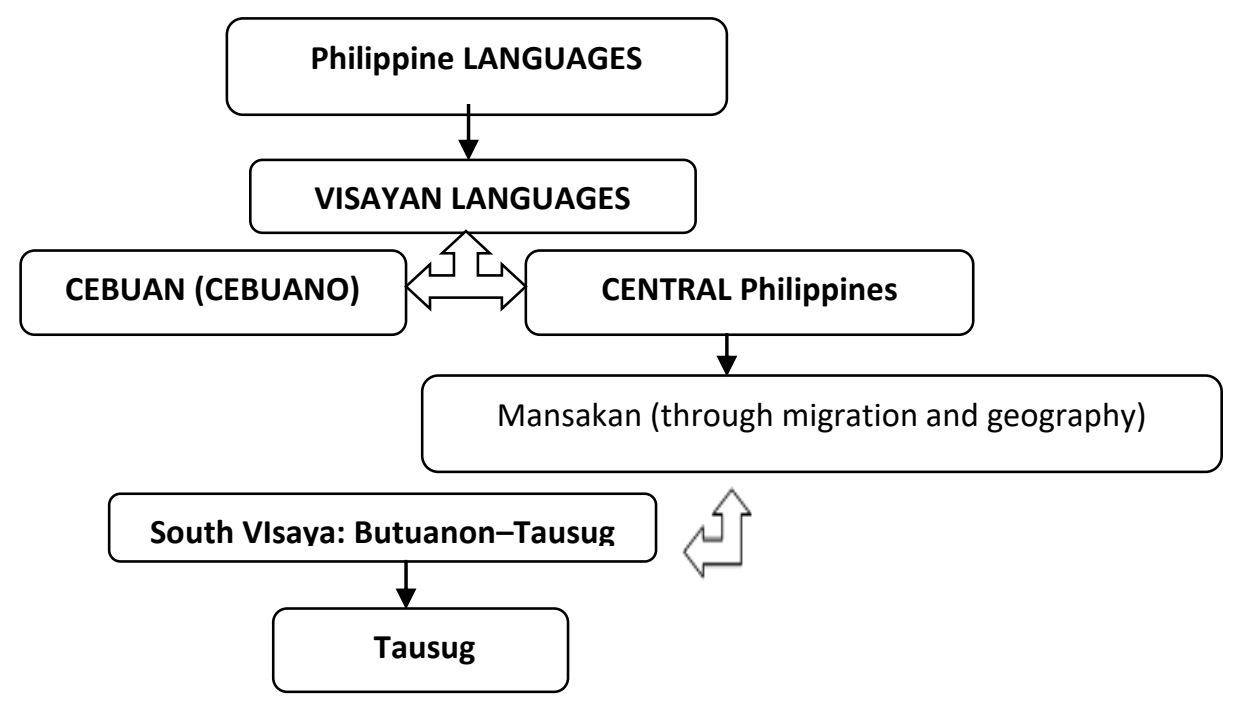

Based on the original subgrouping of BLUST, the diagram shows that one factor that created the many similarities in lexical features of both Tausug and Bisaya is they are both under the VISAYAN LANGUAGES. That is the main reason why most of their everyday words are exactly the same. Historically speaking, the VISAYAN languages are dominated by NON- MUSLIM cultures. There is an exemption, however. In the case of TAUSUGS, they may sound like the BISAYA but since the TAUSUG culture are dominantly MUSLIM, they are more linked to their MINDANAO counterparts—the Bangsamoro group. This would imply that it is not ONLY the geography that can influence a language, it can also be associated with the environment and values you grew up with. Tracing their linguistic history, TAUSUGS are VISAYANS but with their religion, they are marked as MINDANAONS.

Another implication is that the cognates between the Tausug and Bisaya fall into the idea of Ross and Pawley about the facts they associate with tracing the genetics of the language. One is that language's meanings and sounds are arbitrary. This means that the meanings depend on the users and how they understand it. The samples given below would show that Bisaya and Tausug really come from one family because they use the same word and of the same meaning. It would imply that these cultures have their shared views, values and probably beliefs.

\begin{tabular}{|c|c|l|l|}
\hline ENGLISH & SAME WORD & Semantic Field & ONTOLOGY \\
\hline Liver & Atay & The body & Person/thing \\
\hline Shoulder & Abaga; & The body & Person/thing \\
\hline Tongue & Dila & The body & Person/thing \\
\hline Tail & Ikug & The body & Person/thing \\
\hline
\end{tabular}

Another fact is that language sound changes over time and these changes are regular. What the authors mean in this part that the sounds might be substituted with $\mathrm{x}$ or the sound $\mathrm{s}$ might be replaced with $\mathrm{CH}$. This can also be attributed to the cultures' enunciation and pronunciation. If modified, these changes can also mean the dropping or adding a letter that is unique to a culture. Take a look at the samples below:

\begin{tabular}{|c|c|c|c|c|}
\hline ENGLISH & TAUSUG & BISAYA & SEMANTIC FIELD & ONTOLOGY \\
\hline Below & Laum & Ilalum & Spatial relations & Property \\
\hline This & Ini & Kini & Spatial relations & Property \\
\hline Far & Malayu & Layu & Spatial relations & Property \\
\hline New & Bahgu & Bag'u & time & Property \\
\hline Two & Duwa & Duha & quantity & Action/process \\
\hline Die & Matay & Mamatay & motion & Action/process \\
\hline Come & Kari & Ari/ anhi & motion & Action/process \\
\hline Split & Sipak & Tipak & motion & Action/process \\
\hline To fly & Lumupad & Lupad & motion & Action/process \\
\hline Sleep & Tuug & Tulog & .
\end{tabular}


This can also be supported with Blust's (1985) concept of 'environmental' change. For him, a language can be changed in two environmental phenomena: the alternation as well as the migration. It can be because of the migration, the culture adapted to the new environment or society or culture that they have settled in. IT can also be altered by time and distance and changes in the environment--- meaning technology, inventions or new beliefs.

\section{Conclusion}

This paper was initiated for the purpose of comparing the lexicons that are similar to the Bisayan and the Tausug languages. The researcher had used the Samarin list in comparing the words and categorized by means of semantic field and ontological category. Moreover, it is the objective of the paper to identify the factors that demonstrate the relationship of both languages. The discoveries from this study can be of great help in understanding the languages that have cognates and how these cognates help people in better appreciating Bisaya and Tausug. The Tausug and Bisayan (Cebuano) cultures have been traced to come from the same linguistic family. Both belong to the Philippine VISAYAN LANGUAGES. Of all the Visayan cultures, the TAUSUG is a Muslim dominated culture which makes it the reason why people associate Tausug language as part of the Mindanao language. In addition, the Tausugs have embraced Islam and they have also embraced the ways and means as well as MORO identity of their counterparts in Mindanao like dominant cultures of the Meranaws and Maguindanaons. Because of the close relationship of these two cultures, their language components are also almost similar. The researcher had found out that from the 196 lexicons used based on a Samarin list, 72 of those are true cognates and 28 are cognates with few differences and changes in the spelling.

The findings also indicate that these similarities can be attributed to different factors like tracing language relationship by means of genetics, the environmental changes, the language sounds, and language arbitrariness. All these would imply that the cognates of words or lexicons can establish the relationship of two or more languages. Although the paper focused on the similarities of the lexicons of two languages from many languages in the Philippines, the paper intended to find out how they are connected by tracing their roots. The researcher recommends that other languages in the Philippines can also be studied, not just its lexicons but also other components of the language. It is also a good study to cover and research other Asian languages' varieties especially those that are traced to have similarities in terms of language origin. Moreover, studying in general how languages around the word are interconnected will yield fruitful results.

Funding: This research received no external funding.

Acknowledgments: The researcher would like to acknowledge her institution for giving her opportunities and letting her spread her wings and explore the research world, she would also like to give her warm gratitude to her family, who served as her support system all throughout.

Conflicts of Interest: The author declares no conflict of interest.

\section{References}

[1] Brock-Utne, B. (2005). The interrelationship between language and culture. Evaluation of education-on whose terms, 115-129.

[2] BLust, R. (1985). The Austronesian homeland: a linguistic perspective. Asian perspectives. XXVI (1). De Jong, R. (2010). The last tribes of Mindanao. Things Asian._Retrieved from https://bit.ly/36EvYew

[3] Ibn AL-Khutub, M. (2012). The Tausug orthography. Moro Bloggers Central Aggregator.

[4] Kilgour, D. (1999). The Importance of Language. Southern Alberta Heritage Language Association Calgary. http://www.david-kilgour.com/mp/sahla.htm

[5] Litogo. The Dialectology of Cebuano : Cebuano, Bisaya and Binisaya. https://bit.ly/2LID93K

[6] Pawley, A., \& Ross, M. (1995). The prehistory of Oceanic languages: a current view. The Austronesians, 39-74. 